Ivana Bešlić ${ }^{1}$

Dragana Bešlić ${ }^{2}$

Dejan Jakšić ${ }^{3}$

Mirko Andrić ${ }^{4}$
JEL: C30, L60, M21, M41

DOI: 10.5937/industrija43-8035

UDC: 005.332.8:336

658.141 .17

Original Scientific Paper

\title{
Testing the Models for Detection of Earnings Management
}

\author{
Article history: \\ Received: 5 April 2015 \\ Sent for revision: 27 April 2015 \\ Received in revised form:3 September 2015 \\ Accepted: 3 September 2015 \\ Available online: 15 October 2015
}

\begin{abstract}
In this paper authors analyze the predictive power of existing models for the detection of earnings management of the companies in countries around the world. In addition, based on a representative sample of companies in the industrial sector of the Republic of Serbia, they tend to develop an improved model for the detection of manipulative financial reporting, which will be suitable for the Serbian business environment by using multiple linear regression. The application of existing models of discretionary accruals in the Serbian economic environment shows that these predictive models do not have sufficient explanatory power (Jones model 5.4\%; Dechow model 2.6\%; Kasznik model 37\%), and there is a need for their further modifications. From these models, only Kasznik model proved to be statistically significant model for the sample of 65 companies in the industrial sector of the Republic of Serbia. As a result of the research, a modified model of discretionary accruals has been developed, which has improved explanatory power and which allows detection of new techniques of manipulation of financial reporting in the industrial sector of the Republic of Serbia. The explanatory power of our modified model is $63.7 \%$.
\end{abstract}

Keywords: earnings management; industrial sector; Serbia; modified model of discretionary accruals.

\footnotetext{
${ }^{1}$ Business School, Novi Sad, Serbia, beslic.ivana@yahoo.com

${ }^{2}$ Business School, Novi Sad, Serbia

3 University of Novi Sad, Faculty of Economics, Subotica, Serbia

${ }^{4}$ University of Novi Sad, Faculty of Economics, Subotica, Serbia
} 
Bešlić I. et al.: Testing the Models for Detection of Earnings Management

\title{
Testiranje modela za otkrivanje uobličavanja finansijskog rezultata
}

\begin{abstract}
Apstrakt: $U$ ovom radu autori analiziraju predikcionu moć postojećih modela za otkrivanje uobličavanja finansijskog rezultata privrednih društava u zemljama širom sveta. Takođe, na bazi reprezentativnog uzorka privrednih društava u industrijskom sektoru Republike Srbije, autori nastoje razviti poboljšan model za otkrivanje manipulativnog finansijskog izveštavanja pogodan za srpsko poslovno okruženje primenom višestruke linearne regresije. Primena postojećih modela diskrecionih razgraničenja u srpskom ekonomskom okruženju pokazuje da ovi predikcioni modeli nemaju zadovoljavajuću objašnjavajuću moć (Jones model 5,4\%; Dechow model 2,6\%; Kasznik model 37\%), te postoji potreba za njihovim daljim modifikacijama. Od pomenutih modela, samo Kasznik model se pokazao kao statistički značajan model na posmatranom uzorku od 65 privrednih društava $u$ industrijskom sektoru Republike Srbije. Kao rezultat istraživanja razvijen je modifikovan model diskrecionih razgraničenja koji ima poboljšanu objašnjavajuću moć i koji omogućava otkrivanje novih tehnika manipulativnog finansijskog izveštavanja $u$ industrijskom sektoru Republike Srbije. Objašnjavajuća moć našeg modifikovanog modela je 63,7\%.
\end{abstract}

Ključne reči: uobličavanje finansijskog rezultata, industrijski sektor, Srbija, modifikovan model diskrecionih razgraničenja.

\section{Introduction}

Corporate accounting scandals that have occurred in the last decade around the world, for example in the United States (Xerox, Enron, WorldCom, Health South, etc.), Europe (Parmalat, Vivendi, etc.) and Asia (Satyam Computer Services, Sino-Forest, etc.) were usually accompanied by a number of accounting manipulations. Business operations of these companies ranged from allowed creative shaping of financial results to the fraud or misrepresentation of financial statements.

Manipulative financial reporting includes all activities of shaping the financial statements by the management or third parties, which can be permissible but also may be a form of the violation of professional and legal regulations with the aim of deceiving users of financial statements, obtaining benefits or increasing the amount of compensation (salary) or bonuses, tax cuts on income, fulfillment of loan requests and meeting external expectations (expectations of financial analysts, investors, etc.). According to Jakšić and Vuković (2012) "manipulative financial reporting" cannot be equated conceptually with "criminal activities affecting the financial statements." The manipulation of financial statements is a narrower term, or is only one of the 
Bešlić I. et al.: Testing the Models for Detection of Earnings Management

possible forms of criminal activities affecting the financial statements (Jakšić \& Vuković, 2012). Due to inaccurate, imprecise and generally inadequate valuation of balance sheet positions, there is a phenomenon of false balance sheets, hidden financial results, latent reserves and losses. The underestimation of assets and overestimation of liabilities in the balance sheet leaves room for the creation of latent reserves. The hidden losses are due to overestimation of assets and underestimation of liabilities and affect the inclusion of lower expenses in the income statement and increase in financial results. Manipulative financial reporting has many negative consequences (Collingwood, 2001): 1. loss of confidence of users of financial statements in the credibility and reliability of financial reporting, 2. loss of credibility of the accounting and auditing profession, 3. degradation of the efficiency and effectiveness of corporate governance, 4. bankruptcy and huge financial losses of the company that resorts to manipulative financial reporting, and 5. the reduction of efficiency of the financial markets and the economy as a whole.

This paper is divided into 6 sections: 1 . introduction, 2.hipotesis development, 3. materials and methods, 4. results and discussion, 5. conclusions and 6. references.

\section{Hypothesis Development}

Earnings management is the active manipulation of accounting results for the purpose of creating an altered impression of business performance (Mulford \& Comiskey, 2002). There are different strategies for earnings management such as: "income smoothing", "big bath", "aggressive accounting". "Cookie jar reserves" is an income smoothing technique. It occurs when expenses are based on estimates. If the company over-estimates expenses, then it may choose to use a portion of the expenses in one accounting period and save the other for future accounting periods. Generally, to smooth income, managers create "reserves" in periods of good performance, in order to use them to increase earnings in periods of poor performance, making, hence, the reported earnings actually less variable than the true company's economic performance (Leuz, Nanda \& Wysocki, 2003). "Big bath accounting" is the use of earnings management to manipulate poor earnings downwards so they become even poorer. The idea behind it all is that in the subsequent years, the chance of showing higher returns increases (Kirschenheiter \& Melumad, 2002). "Aggressive accounting" is the use of optimistic projections or gray areas in the accounting standards to create financial statements that present a rosier picture of a company than is actually the case. Beaver (2002) suggests that earnings management can improve or impair the quality of earnings through the exercise of discretion over accounting numbers. 
Bešlić I. et al.: Testing the Models for Detection of Earnings Management

Discretionary behavior includes voluntary earnings forecasting, voluntary disclosure, choice of accounting methods, and estimation of accruals. The management is under increasing pressure to achieve the satisfactory gain in harsh operating conditions, so they misuse flexibility in financial reporting based on the choice of alternative accounting methods and estimates foreseen by accounting standards (for example, the FIFO method and the weighted average cost method, the method of linear depreciation and declining balance depreciation method, the assessment of debt collection, evaluation at fair value, etc.). Jeanjean and Stolowy (2008) studied earnings management before and after the IFRS conversion in France, UK and Australia. Their results indicated that the level of earnings management had not declined after switching to IFRS, in fact earnings management had increased in, for instance, France after the transition.

The manipulation of reports is characteristic of countries in transition, where the economic situation is insufficiently stable with a large number of companies managed by incompetent management. Likewise business operations in the global economic and financial crisis (recession period) are characterized by the existence of numerous risk factors of manipulation of financial statements. Salustro and Leburn (2000) find that managers often resort to manipulative practices of financial reporting in the crisis period (Asif, Rehana, \& Md. Mamunur, 2011). The effects of the global economic crisis began to be felt in the Republic of Serbia and other Western Balkan countries in the second half of 2008. The decline in industrial production is higher, along with a decline in exports and imports, and domestic trade (Bešlić \& Bešlić, 2009). The impact of the global financial crisis on the business activities of companies in the Republic of Serbia is reflected on a decline in demand for products both in the international and domestic market, which led to the creation of stocks, production cuts, lack of full employment of labor, worsened liquidity, difficulties in collection of receivables and settlement of accrued liabilities, etc. (Andrić \& Vuković, 2012). In the second half, and especially the last quarter of 2011, Serbia faced the recession. For that reason, Serbia's real economic growth amounted to $1.6 \%$. Fiscal deficit increased from planned $4.1 \%$ of gross domestic product to $4.5 \%$ of gross domestic product, which caused the increase of public debt above the projected limit of $45 \%$ of GDP (Arsić, 2011).

According to most of the previous research studies, the most reliable models to detect manipulative financial reporting, i.e. shaping gain using discretion right of the management in the choice of accounting methods and estimates are models of discretionary accruals: Jones model (1991) and modified Jones models (Dechow model (1995), Kasznik model (1999), etc.) (Peasnell, 2000). The estimated value of discretionary accruals can be positive or negative (Tilden \& Janes, 2012), because the manipulation of financial statements can be directed towards achieving the desired management objectives (Sandeep, 
Bešlić I. et al.: Testing the Models for Detection of Earnings Management

2012): 1. to increase the financial results (income increasing) or 2. to reduce financial results (income decreasing). Existing models of discretionary accruals have different explanatory power in countries around the world (Roodposhti, Banimahd, Rezaei \& Salehi, 2012; Md. Borhan, Jamal \& Murray, 2013). Each model has the advantage of detecting only one aspect of manipulating the financial results of the company, and there are still attempts for developing an improved model for the detection of manipulative financial reporting. Therefore the following research hypothesis is proposed:

$\boldsymbol{H}_{1}$ : The application of the developed model of discretionary accruals may detect earnings management in the industrial sector of the Republic of Serbia.

During the development and implementation of the model for detection of earnings management of the company turned out that it is necessary to adjust the model to the type of the company that is being evaluated, as well as to adapt it to the specific conditions of the countries or regions in which companies operate. The aim of this paper is to detect earnings management practices within Serbian industrial companies based on the improved model that would reflects the techniques of manipulating reported earnings in Serbian context.

\section{Materials and Methods}

\subsection{Specific Features of Models of Discretionary Accruals in Detecting Earnings Management}

Jones (1991) proposes a model that attempts to control the effects of changes in a firm's economic circumstances on non-discretionary accruals. This model indicates that changes in total assets, gross revenue, and gross property plant and equipment (PPE) are the determinants of non-discretionary accruals. The idea of the Jones (1991) model is that sales revenue proxies for the economic events that generate current non-discretionary accruals, while gross PPE controls for non-discretionary accruals related to depreciation expense. Thus the Jones (1991) model is based on two key assumptions. Firstly, sales revenue is assumed to be unmanaged. Secondly, changes in current assets and liabilities are assumed to be driven by changes in sales revenue. The specific features of the Jones model (1991) include: 1. abandoning the assumption that non-discretionary accruals are constant over time and 2 . attempt to control the effects of changes in operating performance of the company over the measurement of non-discretionary accruals. The limitation of the model is that it ignores the potential managerial manipulation of revenues (Jones, 1991). 
Bešlić I. et al.: Testing the Models for Detection of Earnings Management

Jones (1991) uses a three-stage approach to bifurcate total accruals into their discretionary (managed) and non-discretionary components. In the first stage, total accruals (TA) are estimated using balance sheet approach. In the second stage, the model was used for computing non-discretionary accruals (NDA). All variables in the original models are deflated by total assets at the beginning of the year (year $t-1$ ) to mitigate heteroscedasticity. In the third stage, after computing total accruals (TA) and non-discretionary accruals (NDA), discretionary accruals (DA) were computed using equation: $\mathrm{DA}_{\mathrm{it}}=\mathrm{TA}_{\mathrm{it}}$ $-\mathrm{NDA}_{\mathrm{it}}$.

According to the contemporary researchers (authors), all variables in accrual models (Jones model and other accrual models) are deflated by average total assets to mitigate potential heteroscedasticity in the variables (Larcker \& Richardson, 2004; Stubben, 2010; Wang \& Xin, 2011; Algharaballi, 2012). We supported this approach in our research study.

The following equation is the Jones model:

$\frac{T A_{i t}}{A_{(\boldsymbol{t}-\mathbf{1}+\boldsymbol{t}) / 2}}=\beta_{0} * \frac{1}{A_{(\boldsymbol{t}-\mathbf{1}+\boldsymbol{t}) / 2}}+\beta_{1} *\left(\frac{\Delta R E V_{i t}}{A_{(\boldsymbol{t}-\mathbf{1}+\boldsymbol{t}) / 2}}\right)+\beta_{2} *\left(\frac{P P E_{i t}}{A_{(\boldsymbol{t}-\mathbf{1}+\boldsymbol{t}) / 2}}\right)+\varepsilon_{i t}$;

Where:

$\mathrm{TA}_{\mathrm{it}}$ - total accruals for the company $i$ in the current period $t$;

$\mathrm{A}_{(\mathrm{t}-1+\mathrm{t}) / 2}$ - average total assets;

$\beta_{0}, \beta_{1}, \beta_{2}-$ estimated parameters or regression coefficients;

$\varepsilon_{i t}-$ residual variable or earnings management (EM);

$\triangle R E V_{i t}$ - change in net sales revenues of the company $i$ in the current year $t$ compared with the previous year $t-1$;

$\mathrm{PPE}_{\mathrm{it}}$ - gross value of property, plant and equipment for the company $i$ in the current year $t$.

Different researchers (authors) around the world used different ways to define total accruals. The two most popular methods for computing total accruals referred to as the balance sheet approach (Healy, 1985; Jones, 1991) and the cash flow approach (Chen, Lin, \& Zhou, 2005; Naveed, Saif, Qaisar, \& Shoaib, 2012; Fawzi, 2014) have been utilized extensively in the research literature. The balance sheet approach measures accruals as the change in accounts from successive balance sheets and relies on the presumed articulation between changes in working capital balance sheet accounts and accrual components of revenues and expenses on the income statement. This approach has been dominant in the research, having been the only method available for estimating total accruals prior to the Statement of Financial Accounting Standards (SFAS) No. 95: Statement of Cash Flows (FASB, 1987). 
Bešlić I. et al.: Testing the Models for Detection of Earnings Management

The balance sheet approach typically computes total accruals (TA) as follows:

$T A_{t}=\Delta C A_{t}-\Delta C L_{t}-\Delta \operatorname{Cash}_{t}+\Delta S T D E B T_{t}-D E P_{t}$

Where:

$\Delta \mathrm{CA}_{\mathrm{t}}-$ Change in current assets between current year $t$ and previous year $t-1$;

$\Delta C L t-$ Change in current liabilities between current year $t$ and previous year $t-1$;

$\Delta$ Casht - Change in cash and cash equivalents between current year $t$ and previous year $t-1$;

$\triangle$ STDEBT $_{\mathrm{t}}-$ Change in current maturities of long-term debt and other short term debt included in current liabilities between current year $t$ and previous year $t-1$;

DEPt - Depreciation and amortization in the current year $t$.

Conversely, the cash flow approach measures accruals directly from the statement of cash flows. If applicable to the data in question, the use of the cash flow approach is less computationally demanding and considered more effective at computing total accruals. Hribar and Collins (2002) conclude that the use of the balance sheet approach introduces significant measurement error into accrual estimates because the partitioning variable is often correlated with the occurrence of non-operating events such as reclassifications, acquisitions, divestitures, accounting changes, and foreign currency translations. This non-articulation problem can contaminate the estimation of abnormal accruals and lead to the erroneous conclusion that earnings management exists when no such opportunistic activity actually occurs. The authors advocate the use of the cash flow approach where applicable - except for studies using pre SFAS No. 95 data, where "additional specification tests should be conducted to control for possible errors in accrual measurement".

Hribar and Collins (2002) show that calculating accruals using balance sheet data (i.e. the indirect method) may cause some errors, therefore we test the models with total accruals (TA) (discretionary and non-discretionary accruals) calculated using the net cash flow from operations reported in the cash flows statement (i.e. the direct method). $\mathrm{TA}_{\text {it }}$ (total accruals) $=\mathrm{Nl}_{\text {it }}$ (net income) $\mathrm{CFO}_{\text {it }}$ (net operating cash flow or net cash flow from operating activities) according to (Hribar \& Collins, 2002). 
Bešlić I. et al.: Testing the Models for Detection of Earnings Management

$$
\begin{aligned}
& T A_{i t}=\frac{T A_{i t}}{A_{(t-1+t) / 2}} ; \text { that is } T A_{i t}=\frac{D A_{i t}}{A_{(t-1+t) / 2}}+\frac{N D A_{i t}}{A_{(t-1+t) / 2}} ; D A_{i t}=\frac{T A_{i t}}{A_{(t-1+t) / 2}}- \\
& \frac{N D A_{i t}}{A_{(t-1+t) / 2}} ; D A_{i t}=\frac{N I_{i t}-C F O_{i t}}{A_{(t-1+t) / 2}}-\left(\beta_{0} * \frac{1}{A_{(t-1+t) / 2}}+\beta_{1} *\left(\frac{\Delta R E V_{i t}}{A_{(t-1+t) / 2}}\right)+\beta_{2}\right. \text { * } \\
& \left.\left(\frac{P P E_{i t}}{A_{(t-1+t) / 2}}\right)\right) .
\end{aligned}
$$

\section{Where:}

$\mathrm{DA}_{\mathrm{it}}$ - discretionary accruals for the company $i$ at the time of estimation;

$\mathrm{NDA}_{\mathrm{it}}$ - non-discretionary accruals for the company $i$ at the time of estimation;

Jones model (1991) was used as the basis for many other, later developed models. Dechow, Sloan, and Sweeney (1995) presented an improved version of the original Jones model, or modified Jones model (Dechow model). The modified Jones model or Dechow model (1995) was developed to eliminate the supposed tendency of erroneous measurements of discretionary accruals when managers use the discretion right for revenues (eliminate managerial discretion through the sale on credit).

The following equation is the Dechow model:

$$
\frac{T A_{i t}}{A_{(t-1+t) / 2}}=\beta_{0} * \frac{1}{A_{(t-1+t) / 2}}+\beta_{1} *\left(\frac{\Delta R E V{ }_{i t}-\Delta R E C}{A_{(t-1+t) / 2}}\right)+\beta_{2} *\left(\frac{P P E_{i t}}{A_{(t-1+t) / 2}}\right)+\varepsilon_{i t} \text {; }
$$

$T A_{i t}=\frac{T A_{i t}}{A_{(t-1+t) / 2}}$ that is $T A_{i t}=\frac{D A_{i t}}{A_{(t-1+t) / 2}}+\frac{N D A_{i t}}{A_{(t-1+t) / 2}} ;$

$D A_{i t}=\frac{N I_{i t}-C F O_{i t}}{A_{(t-1+t) / 2}}-\left(\beta_{0} * \frac{1}{A_{(t-1+t) / 2}}+\beta_{1} *\left(\frac{\Delta R E V_{i t}-\Delta R E C}{A_{(t-1+t) / 2}}\right)+\beta_{2} *\right.$ $\left.\left(\frac{P P E_{i t}}{A_{(t-1+t) / 2}}\right)\right)$.

\section{Where:}

$\triangle \mathrm{REC}_{\mathrm{it}}$ - changes in net receivables from sales in the current year $t$ compared with the previous year $t-1$.

Unlike Dechow model (1995), the modified Jones cash flow model - Kasznik model (1999) includes another independent variable that tracks changes in net cash flow from operating activities of the company $i$ in the current year $t$ compared with the previous year $t-1$ (Matis, Beattrice, \& Negrea, 2009):

The following equation is the Kasznik model: 
Bešlić I. et al.: Testing the Models for Detection of Earnings Management

$$
\begin{aligned}
& \frac{T A_{i t}}{A_{(t-1+t) / 2}}=\beta_{0} * \frac{1}{A_{(t-1+t) / 2}}+\beta_{1} *\left(\frac{\Delta R E V_{i t}-\Delta R E C}{A_{(t-1+t) / 2}}\right)+\beta_{2} * \\
& \left.\left(\frac{P P E_{i t}}{A_{(t-1+t) / 2}}\right)+\beta_{3} * \frac{\Delta C F O_{i t}}{A_{(t-1+t) / 2}}\right)+\varepsilon_{i t} \\
& T A_{i t}=\frac{T A_{i t}}{A_{(t-1+t) / 2}} \text { that is } T A_{i t}=\frac{D A_{i t}}{A_{(t-1+t) / 2}}+\frac{N D A_{i t}}{A_{(t-1+t) / 2}} ; \\
& D A_{i t}=\frac{N I_{i t}-C F O_{i t}}{A_{(t-1+t) / 2}}-\left(\beta_{0} * \frac{1}{A_{(t-1+t) / 2}}+\beta_{1} *\left(\frac{\Delta R E V_{i t}-\Delta R E C}{A_{(t-1+t) / 2}}\right)+\beta_{2} *\right. \\
& \left.\left.\left(\frac{P P E_{i t}}{A_{(t-1+t) / 2}}\right)+\beta_{3} * \frac{\Delta C F O_{i t}}{A_{(t-1+t) / 2}}\right)\right) .
\end{aligned}
$$

Roodposhti, Banimahd, Rezaei, and Salehi (2012) examined the explanatory power of the Jones model (1991), Dechow model (1995), Kasznik model (1999) and Kothari-Jones model (2005) on a sample of 73 companies from Tehran, Iran. According to these authors, Kothari-Jones model or Performance Matched Model (2005) had the highest explanatory power. The explanatory power of the model Jones was $11.5 \%$; Dechow model had $4.4 \%$; Kasznik model had 4.2\%; Kothari-Jones model had $30.1 \%$ and modified Kothari-Jones model had 29.1\%. Md. Borhan, Jamal and Murray (2013) examined the explanatory power of the Jones model (1991), Dechow model (1995), Kothari-Jones model (2005) on a sample of 70 companies from New Zealand. Jones model (1991) has 20.4\% explanatory power; Dechow model (1995) has 20.1\% explanatory power; The Kothari-Jones model (2005) has $31.6 \%$ explanatory power. Thus, the modified Jones model (1995) proved to be the best model for detecting manipulation of financial results, which is consistent with earlier empirical studies conducted in the United States, Malaysia, Taiwan, India, etc.

Models for the detection of manipulative financial reporting evaluate the effects of accounting manipulations, i.e. the absolute value of discretionary accruals for the period of one year. If the discretionary accruals are significantly different from zero, this means that in the reporting period there is a practice of manipulating the financial results of the company. The direction of managing financial results is a sign of discretionary accruals (plus sign (+) means an increase in the financial results, whereas minus sign (-) means a decrease in the financial result). There is an opinion that the different explanatory power of these accounting model as a technique to detect manipulative financial reporting varies from country to country, because it is strongly influenced by the heterogeneity of the sample of companies for the assessment of the strength and direction of the correlation between the variables included in predictive models, specific characteristics of business 
Bešlić I. et al.: Testing the Models for Detection of Earnings Management

companies in countries around the world, changes in the economic environment and so on (De las Heras, Canibano, \& Moreira, 2012). Taking into account the papers of other authors who developed models for determining the size of discretionary accruals as a measure for the detection of earnings management of the company, in our research we decided to analyze the application of multiple linear regression. Descriptive statistics will be used for checking the descriptive statistical indicators. Pearson correlation and multiple regression analysis will be used to check the hypothesis of research. ANOVA procedure in regression analysis will test the assertion that the coefficient of multiple determinations in a population is different from zero, i.e. this test will check the validity of the regression model from the statistical point of view. Discretionary accruals will be obtained as the residual of a multiple regression model $\left(\varepsilon_{i}=e_{i}=Y_{i}-\hat{Y}_{i}\right)$. A higher level of discretionary accruals, positive or negative, indicates a greater level of earnings management. For each model we will use multiple regression analysis in assessing and predicting the value of the metric dependent variable $Y$ (total accruals) based on the values of two or more independent variables $X$ (predictors or factors) of the model, which are correlated with it. Multiple linear regression model will express the analytical relationship in which one dependent variable depends on two or more independent variables. The general form of a multiple linear regression model is as follows (SoldićAleksić, 2011):

$Y_{i}=\beta_{0}+\beta_{1} * X_{1}+\beta_{2} * X_{2}+\beta_{3} * X_{3}+\ldots+\beta_{i} * X_{i}+\varepsilon_{i} ; \quad \mathrm{i}=1,2, \ldots, \mathrm{n}$.

(population)

$Y_{i}=\beta_{0}{ }^{\wedge}+\beta_{1}{ }^{*} X_{1}+\beta_{2}{ }^{*} X_{2}+\beta_{3}{ }^{*} X_{3}+\ldots+\beta_{i}{ }^{*} X_{i}+e_{i} ; \mathrm{i}=1,2, \ldots, \mathrm{n}$.

Where: $Y_{i}=$ the dependent variable, $X_{i}=$ the independent variable, $\beta i=$ regression parameter of the $i$ independent variable, $\varepsilon_{i}=e_{i}=$ stochastic member, i.e. random error, which reflects all the influences on the dependent variable that does not originate from the independent variables $X_{i}, n=$ size of the basic set, i.e. the sample.

Here are some steps to note about estimating the regression model:

1. The model will be estimated using annual data from financial statements of companies in the industrial sector of the Republic of Serbia.

2. It is important to choose financial indicators (variables) that will be used for the development of model; 
Bešlić I. et al.: Testing the Models for Detection of Earnings Management

3. The cash flow approach will be used to compute total accruals;

4. All variables in these models are deflated by average total assets $\left(\mathrm{A}_{(\mathrm{t}-1+\mathrm{t}) / 2}=\right.$ (assets at the beginning of the year + assets at the end of the year) / 2) to mitigate heteroscedasticity;

5. The specific regression parameters or regression coefficients $\beta\left(\beta_{0}\right.$, $\beta_{1}, \beta_{2}, \ldots, \beta_{n}$ will be estimated for selected variables in the model;

6. After computing total accruals (TA) and non-discretionary accruals (NDA), discretionary accruals (DA) were computed indirectly, using equation: $\mathrm{DA}_{\mathrm{it}}=\mathrm{TA}_{\mathrm{it}}-\mathrm{NDA}_{\mathrm{it}}$.

Quantitative statistical analysis will be conducted on a computer using the statistical software package IBM SPSS Statistics Version 20.0. When conducting the analysis phase of the research to test the defined hypotheses formulation and concluding remarks, the symbiosis of methods of observation, measurement, interpretation, comparison and analysis will be used.

\subsection{Sample Selection}

The selection of companies will be carried out by random sampling according to the availability of financial statements from the website of the Business Registers Agency of the Republic of Serbia (Business Registers Agency of the Republic of Serbia, 2014). The final sample consists of 65 companies in the industrial sector of the Republic of Serbia. The observed time period is from 2010 to 2011, and the impact of the global financial crisis on the decision of companies to shape the financial result will be analyzed for the period. A period of this study (2010-2011) is post-IFRS period.

\subsection{The Choice of Financial Indicators Used for the Development of Model}

The existing models of discretionary accruals (Jones model (1991), Dechow model (1995), Kasznik model (1999), etc.) do not include independent variables in order to reveal the effects of the initial and subsequent measurement of inventories and property, plant and equipment on the financial statements. Inventories are valued in accordance with IAS 2 Inventories (The Ministry of Finance of the Republic of Serbia, 2013). They are valued at the historical cost or, net realizable value, if lower. The estimation of the inventories may significantly affect the reality of the reported financial results. If the inventories are estimated at a higher value than the actual cost or net realizable value, a higher financial result will be shown (hidden losses); By the depreciation of inventories, part of the annual profit 
Bešlić I. et al.: Testing the Models for Detection of Earnings Management

can be depreciated and transferred to the next period for distribution (hidden profit).

The selection or the application of an appropriate model of subsequent valuation of property, plant and equipment (cost model or the revaluation model) in a variety of market conditions give different effects on the contributory and financial position of the company (The Ministry of Finance of the Republic of Serbia, 2013). Regardless of the chosen model of measurement after initial recognition, in addition to the depreciation of property, plant and equipment it is necessary to perform the review of impairment in accordance with IAS 16 - Property, plant and equipment. When the fair market value first increases and then decreases, the application of the revaluation model in terms of growth in fair value leads to an increase in the value of assets and capital of the company and vice versa. If a result of the revaluation of property, plant and equipment (buildings, machinery and equipment, etc.) is an increase in reported amounts of assets, the positive effect of the revaluation is credited to revaluation reserves, which increases the equity of the company, and a part of these reserves can be cancelled during the use of the funds transferred to retained earnings from previous years. Negative effects of the estimation are registered by decreasing previously created revaluation reserves on the same basis (and a decrease in the value of own capital), and if this is not enough, it is done on the burden of other expenses.

When after the initial recognition a company opts for the fair value method to measure its investment properties, there are no depreciation and impairment calculations, because these procedures do not apply IAS 40 - Investment property. Effects of the estimation of investment properties are not reported as revaluation reserves (impact on equity), but directly affect to the financial result as revenue or expense for the period. One of the primary causes of the global financial crisis in mid-2008 is the improper application of the fair value method, which inflates the value of assets and displays fictitious gain. In the foreign literature there is an opinion that the estimated discretionary accruals based on the model to detect manipulative financial reporting may lead to serious errors in measurement, if you do not include the Return on Assets (ROA). Table 1 presents summary of financial indicators used in the development of the model.

For the purposes of this study stepwise statistical regression - Forward method to select the independent variables of the model will be applied (Pallant, 2009). In the Forward method the independent variables are gradually included in the model, with assumption that there are not any independent variables in the model. The inclusion of independent variables in the model is determined by "contribution" of each specific variable to explaining the variability of the dependent variable. The standard value of the 
Bešlić I. et al.: Testing the Models for Detection of Earnings Management

$F$ statistic for the inclusion of independent variables in the model is 3.84 , while the corresponding probability $p$ is 0.05 .

Table 1. Summary of financial indicators used in the development of the model

\begin{tabular}{|c|c|}
\hline $\begin{array}{l}\text { Dependent } \\
\text { variable }\end{array}$ & $\begin{array}{l}\text { - } T A=\text { (net income in the current year } t \text { minus }(-) \text { net cash flow from } \\
\text { operating activities in the current year } t \text { ) / average value of assets }\end{array}$ \\
\hline $\begin{array}{l}\text { Independent } \\
\text { variables }\end{array}$ & 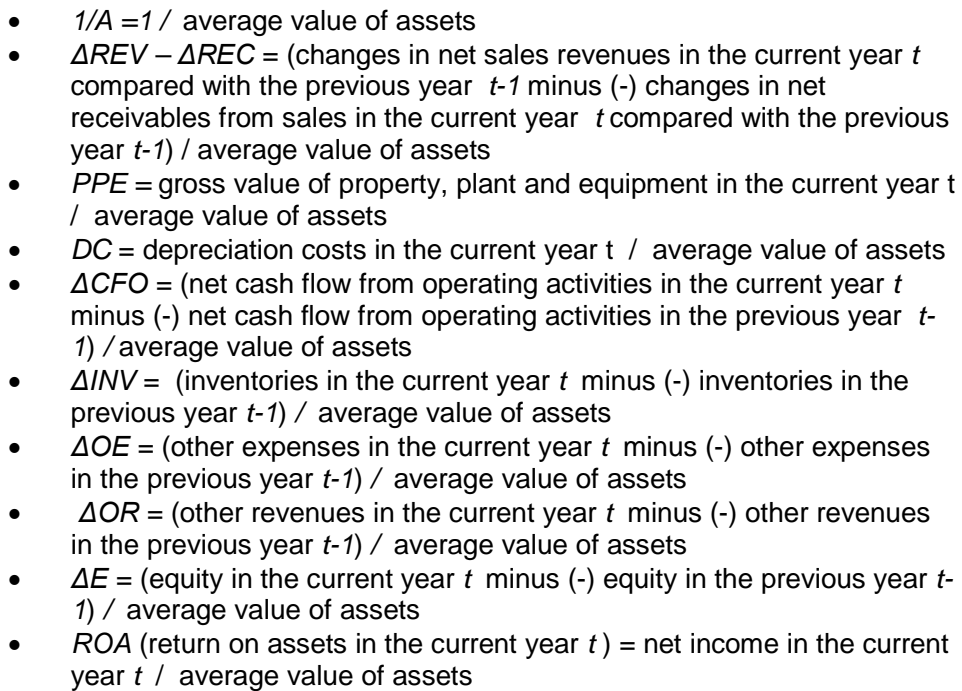 \\
\hline
\end{tabular}

Source: authors' research

\section{Results and Discussion}

\subsection{Development of the Modified Model}

First, should be estimated the specific regression parameters or regression coefficients $\beta\left(\beta_{0}, \beta_{1}, \beta_{2, \cdots}, \beta_{n}\right.$ for selected variables in the model. By applying statistical process of model building by the stepwise method, after six iterations the regression model is generated. The regression model included the following six predictors out of 10 applied financial indicators:

1. changes in net cash flows from operating activities in the current year $t$ compared with the previous year $t-1$,

2. return on assets in the current year $t$,

3. depreciation costs in the current year $t$, 
Bešlić I. et al.: Testing the Models for Detection of Earnings Management

4. changes in inventories in the current year $t$ compared with the previous year $t-1$,

5. changes in other expenses in the current year $t$ compared with the previous year $t-1$,

6. difference between changes in the net sale revenues and changes in net receivables from sales.

Unstandardized regression coefficients are used for the presentation of regression equation. On the basis of the calculated regression coefficients for each involved predictor the following a multiple linear regression model to detect manipulation of financial results in the industrial sector of the Republic of Serbia is created:

$T A_{i t}=0.039-0.519 * \Delta C F O_{i t}+0.605 * R O A_{i t}-1.784 * D C_{i t}+0.138 *$ $\Delta I N V_{i t}-0.774 * \Delta O E_{i t}+0.056^{*}\left(\Delta R E V_{i t}-\Delta R E C_{i t}\right)$.

Discretionary accruals (DA) (that is earnings management (EM)) is obtained as the residual $\left(e_{i t}\right)$ from the regression model: $e_{i t}=D A_{i t}=T A_{i t} /$ average value of assets - NDA ${ }_{i t}$ / average value of assets.

That is $e_{i t}=D A_{i t}=\left(N I_{i t}-C F O_{i t}\right) /$ average value of assets $-(0.039-$ $0.519 * \Delta C F O_{i t}+0.605 * R O A_{i t}-1.784 * D C_{i t}+0.138 * \Delta I N V_{i t}-0.774 *$ $\left.\Delta O E_{i t}+0.056^{*}\left(\triangle R E V_{i t}-\Delta R E C_{i t}\right)\right)$.

A period of the study (2010-2011) used to estimate the parameters(coefficients) of the new model is a period of conducting earnings management (event period). The results could be jeopardized because the model was tested after the financial crisis.

Table 2 presents expected sign for each independent variable in the model.

Table 2. Expected sign for each independent variable

\begin{tabular}{|l|c|c|}
\hline \multicolumn{1}{|c|}{ Independent variables } & Expected sign & Coefficient \\
\hline$\Delta \mathrm{CFO}$ & - & - \\
\hline $\mathrm{ROA}$ & + & + \\
\hline $\mathrm{DC}$ & $?$ & - \\
\hline$\Delta \mathrm{INV}$ & $?$ & + \\
\hline$\Delta \mathrm{OE}$ & $?$ & - \\
\hline$\left(\triangle \mathrm{REV} \mathrm{V}_{\text {it }}-\triangle \mathrm{REC}_{\text {it }}\right)$ & + & + \\
\hline
\end{tabular}

Source: authors' research

Using current year ROA rather than lagged ROA yields better results for controlling performance on discretionary accruals (Kothari, Leone \& Wasley, 
Bešlić I. et al.: Testing the Models for Detection of Earnings Management

2005). Several studies include ROA in the model as a proxy for firm performance (for example, McNichols, 2000, Rahman \& Ali, 2006; Ali, Salleh, \& Hassan, 2008). The variable ROA showed positive signal indicating that companies with extreme performance tend to manage more their results. Consistent with prior studies, we expect a positive association between total accruals and ROA. Correlation between total accruals and change in cash from operations is negative as expected (Dechow, Sloan \& Sweeney, 1995). A lower value of this measure (that is, a more negative value) indicates a greater use of accruals to offset fluctuations in cash flows, thus smoothing income series. In fact, as emphasized by Leuz, Nanda \& Wysocki, 2003, management may use its accounting discretion to conceal economic shocks in the company's operating cash flows. For example, it may accelerate the recognition of future profits or delay the recognition of current losses to hide poor current performance. Correlation between total accruals and difference between changes in the net sale revenues and changes in net receivables from sales is positive as expected (Matis, Beattrice, Negrea \& Sucala, 2010).

\subsection{The Evaluation of Models for Detection of Earnings Management of the Companies in the Industrial Sector of the Republic of Serbia}

There are different statistical methods for evaluating the suitability of models of discretionary accruals. The statistical significance of each model is usually tested using the method of analysis of variance, performing F-test (for example, if the Sig. value is less than 0.05 , we can conclude that the model is statistically significant). The essence of the analysis of variance is decomposition of the total variance of the dependent variable on the regression and residual part: the variability that occurs under the influence of controlled factors (explained variability) and residual variability occurred under the influence of others, i.e. uncontrollable factors (unexplained variability). Test relations variance or F-test is a parametric test used to test the difference between two independent estimates of variance (factor and residual variance). The null hypothesis is that the coefficient of determination in the population is equal to zero: $\mathrm{H}_{0}: R^{2}=0$, against the alternative hypothesis that the coefficient of determination is different from zero: $\mathrm{H}_{1}: R^{2} \neq 0$.

F-test equals: $F=\frac{R^{2} / k}{\left(1-R^{2}\right) /(N-k-1)}$

where: $\mathrm{R}^{2}=$ coefficient of determination, $\mathrm{N}=$ sample size, $\mathrm{k}=$ number of independent variables.

The strength of the bond between the dependent variable and independent variables is measured by the coefficient of determination ( $R$ Square). The 
Bešlić I. et al.: Testing the Models for Detection of Earnings Management

application of linear regression model for predicting the value of dependent characteristics is justified if the coefficient of determination is high (it is enough that the coefficient of determination is $\left.\left(r^{2}\right)>0.5\right)$ and the parameter $\beta$ $\neq 0$, with a significance level $\alpha=0.05$ (Joksimović, 2006). Based on the Durbin-Watson test for serial correlation in the residuals it will be determined whether there is autocorrelation in the residuals. If the value of $d$ statistic is $1.7=<d<2.3$ then there is no correlation between residuals that could adversely affect the characteristics of the model. The consequences of the presence of autocorrelation in residuals are the following: inefficient estimates of regression parameters, bias of standard errors of the regression coefficients, so that statistic tests of significance become unreliable (SoldićAleksić, 2011). The statistical significance of this indicator is determined through ANOVA procedure in regression analysis. By applying these tests it is possible to choose the most reliable model to detect manipulative financial reporting.

The coefficient of determination (R Square) for the Jones model indicates that $5.4 \%$ of the variability of the dependent variable (total accruals) can be explained by the regression model. The coefficient of determination ( $R$ Square) for Dechow model shows that $2.6 \%$ of the variability of the dependent variable (total accruals) can be explained by the regression model. The coefficient of determination (R Square) for Kasznik model shows that $37 \%$ of the variability of the dependent variable (total accruals) can be explained by the regression model. The coefficient of determination ( $R$ Square) for our modified model shows that $63.7 \%$ of the variability of the dependent variable (total accruals) can be explained by the regression model. Therefore, we conclude that we should reject the null hypothesis, which means that the coefficient of determination for our regression model is different from zero. Since the value of $d$ statistics is $1.7=<d<2.3$ there is no correlation between residuals that could adversely affect the characteristics of the model. The results are presented in tables of summary statistics (Table 3, Table 4 and Table 5).

Table 3. Summary statistics for the Jones model:

\begin{tabular}{|c|c|c|c|c|c|c|c|c|c|c|}
\hline \multirow[t]{2}{*}{ Model } & \multirow[t]{2}{*}{$\mathrm{R}$} & \multirow{2}{*}{$\begin{array}{c}\mathrm{R} \\
\text { Square }\end{array}$} & \multirow{2}{*}{$\begin{array}{c}\text { Adjusted } \\
\mathrm{R} \\
\text { Square }\end{array}$} & \multirow{2}{*}{$\begin{array}{l}\text { Std. Error of } \\
\text { the Estimate }\end{array}$} & \multicolumn{5}{|c|}{ Change Statistics } & \multirow{2}{*}{$\begin{array}{l}\text { Durbin- } \\
\text { Watson }\end{array}$} \\
\hline & & & & & $\begin{array}{c}\mathrm{R} \\
\text { Square } \\
\text { Change }\end{array}$ & $\begin{array}{c}\mathrm{F} \\
\text { Change }\end{array}$ & $\mathrm{df1}$ & $\mathrm{df} 2$ & $\begin{array}{l}\text { Sig. F } \\
\text { Change }\end{array}$ & \\
\hline $\begin{array}{l}\text { Jones } \\
\text { model }\end{array}$ & .232 & .054 & .007 & .1047908176 & .054 & 1.152 & 3 & 61 & .335 & 1.656 \\
\hline
\end{tabular}

Source: authors' research 
Bešlić I. et al.: Testing the Models for Detection of Earnings Management

Table 4. Summary statistics for the Dechow and Kasznik model

Dechow model: $T A_{i t}=\beta_{0} * 1 / A+\beta_{1} *\left(\triangle R E V_{i t}-\triangle R E C_{i t}\right)+\beta_{2} * P P E_{i t}+e_{i t}$ Kasznik model: $T A_{i t}=\beta_{0}$ * $1 / A+\beta_{1} *\left(\Delta R E V_{i t}-\triangle R E C_{i t}\right)+\beta_{2} * P P E_{i t}+\beta_{3}$ * $\triangle C F O_{i t}+e_{i t}$

\begin{tabular}{|c|c|c|c|c|c|c|c|c|c|c|}
\hline \multirow[t]{2}{*}{ Model } & \multirow[t]{2}{*}{$\mathrm{R}$} & \multirow{2}{*}{$\begin{array}{c}\mathrm{R} \\
\text { Square }\end{array}$} & \multirow{2}{*}{$\begin{array}{c}\text { Adjusted } \\
\text { R } \\
\text { Square }\end{array}$} & \multirow{2}{*}{$\begin{array}{l}\text { Std. Error of } \\
\text { the Estimate }\end{array}$} & \multicolumn{5}{|c|}{ Change Statistics } & \multirow{2}{*}{$\begin{array}{l}\text { Durbin- } \\
\text { Watson }\end{array}$} \\
\hline & & & & & $\begin{array}{c}\mathrm{R} \\
\text { Square } \\
\text { Change }\end{array}$ & $\begin{array}{c}\mathrm{F} \\
\text { Change }\end{array}$ & df1 & $\mathrm{df} 2$ & $\begin{array}{l}\text { Sig. F } \\
\text { Change }\end{array}$ & \\
\hline $\begin{array}{l}\text { Dechow } \\
\text { model }\end{array}$ & .161 & .026 & -.022 & .1063214767 & .026 & .538 & 3 & 61 & .658 & \\
\hline $\begin{array}{l}\text { Kasznk } \\
\text { model }\end{array}$ & .608 & .370 & .328 & .0862319133 & .344 & 32.733 & 1 & 60 & .000 & 2.185 \\
\hline
\end{tabular}

Source: authors' research

Table 5. Summary statistics for the modified model:

$T A_{i t}=$ Constant $+\beta_{0}{ }^{*} \Delta C F O_{i t}+\beta_{1} * R O A_{i t}+\beta_{2} * D C_{i t}+\beta_{3} * \Delta I N V_{i t}+\beta_{4}$ * $\Delta O E_{i t}+\beta_{5}^{*}\left(\Delta R E V_{i t}-\Delta R E C_{i t}\right)+e_{i t}$

\begin{tabular}{|c|c|c|c|c|c|c|c|c|c|c|}
\hline \multirow[b]{2}{*}{$\begin{array}{l}\text { Modified } \\
\text { model }\end{array}$} & \multirow[b]{2}{*}{$\mathrm{R}$} & \multirow[b]{2}{*}{$\begin{array}{c}\mathrm{R} \\
\text { Square }\end{array}$} & \multirow[b]{2}{*}{$\begin{array}{l}\text { Adjusted } \\
\text { R Square }\end{array}$} & \multirow[b]{2}{*}{$\begin{array}{l}\text { Std. Error of } \\
\text { the Estimate }\end{array}$} & \multicolumn{5}{|c|}{ Change Statistics } & \multirow[b]{2}{*}{$\begin{array}{l}\text { Durbin- } \\
\text { Watson }\end{array}$} \\
\hline & & & & & $\begin{array}{l}\text { R Square } \\
\text { Change }\end{array}$ & $\begin{array}{c}\text { F } \\
\text { Change }\end{array}$ & df1 & $\mathrm{df} 2$ & $\begin{array}{l}\text { Sig. F } \\
\text { Change }\end{array}$ & \\
\hline 1 & .566 & .321 & .310 & .0873504961 & .321 & 29.766 & 1 & 63 & .000 & \\
\hline 2 & .662 & .438 & .420 & .0800853445 & .117 & 12.949 & 1 & 62 & .001 & \\
\hline 3 & .733 & .537 & .514 & .0732954362 & .099 & 13.019 & 1 & 61 & .001 & \\
\hline 4 & .760 & .577 & .549 & .0706311793 & .040 & 5.689 & 1 & 60 & .020 & \\
\hline 5 & .781 & .610 & .577 & .0683577321 & .033 & 5.057 & 1 & 59 & .028 & \\
\hline 6 & .798 & .637 & .600 & .0665520127 & .027 & 4.245 & 1 & 58 & .044 & 2.171 \\
\hline
\end{tabular}

Source: authors' research

Based on the output of the ANOVA table, we conclude that Jones model and Dechow model are not statistically significant models for the Serbian business environment (column Sig. > 0.05). Kasznik model is a statistically significant model for the Serbian business environment (column Sig. $=0.000<0.05$ ). 
Bešlić I. et al.: Testing the Models for Detection of Earnings Management

The results are presented in ANOVA tables for existing models: Jones model, Dechow model and Kasznik model (Table 6 and Table 7) and ANOVA table for our modified model (Table 8).

Table 6. ANOVA table

\begin{tabular}{llccccc}
\hline \multirow{2}{*}{ Model } & $\begin{array}{c}\text { Sum of } \\
\text { Squares }\end{array}$ & df & Mean Square & $F$ & Sig. \\
\hline \multirow{3}{*}{ Jones model } & Regression & .038 & 3 & .013 & 1.152 & .335 \\
\cline { 2 - 7 } & Residual & .670 & 61 & .011 & \\
\cline { 2 - 7 } & Total & .708 & 64 & & \\
\hline
\end{tabular}

Source: authors' research

Table 7. ANOVA table

\begin{tabular}{|c|c|c|c|c|c|c|}
\hline \multicolumn{2}{|c|}{ Model } & \multirow{2}{*}{$\begin{array}{c}\begin{array}{c}\text { Sum of } \\
\text { Squares }\end{array} \\
.018\end{array}$} & \multirow{2}{*}{$\frac{d f}{3}$} & \multirow{2}{*}{$\begin{array}{c}\text { Mean Square } \\
.006 \\
\end{array}$} & \multirow{2}{*}{$\begin{array}{c}F \\
0.538\end{array}$} & \multirow{2}{*}{$\begin{array}{l}\text { Sig. } \\
.658\end{array}$} \\
\hline \multirow{3}{*}{$\begin{array}{l}\text { Dechow } \\
\text { model }\end{array}$} & Regression & & & & & \\
\hline & Residual & .690 & 61 & .011 & & \\
\hline & Total & .708 & 64 & & & \\
\hline \multirow{3}{*}{$\begin{array}{l}\text { Kasznik } \\
\text { model }\end{array}$} & Regression & .262 & 4 & .065 & 8.797 & .000 \\
\hline & Residual & .446 & 60 & .007 & & \\
\hline & Total & .708 & 64 & & & \\
\hline
\end{tabular}

Source: authors' research

Table 8. ANOVA table

\begin{tabular}{llccccc}
\hline & Model & $\begin{array}{c}\text { Sum of } \\
\text { Squares }\end{array}$ & df & Mean Square & $F$ & Sig. \\
\hline \multirow{3}{*}{$\begin{array}{l}\text { Modified } \\
\text { model }\end{array}$} & Regression & .451 & 6 & .075 & 16.968 & .000 \\
\cline { 2 - 7 } & Residual & .257 & 58 & .004 & \\
\cline { 2 - 7 } & Total & .708 & 64 & & \\
\hline
\end{tabular}

Source: authors' research

Matis, Beattrice, Negrea and Sucala (2010) compared three models to detect manipulation of financial reporting: Jones model (1991), Dechow model (1995) and Kasznik model (1999) on a sample of 36 companies listed on the Bucharest Stock Exchange and concluded that Jones model is the best model for detecting manipulation of financial reporting (shaping gain) in the 
Bešlić I. et al.: Testing the Models for Detection of Earnings Management

Romanian economic environment. Explanatory power of the Jones model was $16 \%$, whereas explanatory power of the Dechow model was $14.6 \%$, and of the Kasznik model $15.5 \%$. In continental European countries, the original Jones model proved to be the most powerful technique for the detection of shaping the financial results of the company and the destruction of shareholder value.

However, there are different opinions by other authors. Yoon, Miller and Jiraporn (2006) developed a modified Jones model to measure discretionary accruals for Korean companies, because the modified Jones model of 1995 proved to be ineffective for detecting shaping gain in the Korean environment. According to the results of a research study conducted by Alareeni and Aljuaidi (2014), the modified Jones model (1995) shows little predictive power in the Palestinian environment as an emerging market. The explanatory power of the modified Jones model for companies in the industrial sector was $17 \%$, and for companies in the service sector it was 10\%. Also, Md. Aminul, Ruhani and Zamri (2011) found that the modified Jones model (1995) is less efficient for the detection of earnings management when it comes to the capital market in Bangladesh. The explanatory power of the modified Jones model was 8.9\%. Dechow, Sloan and Sweeney (1995) argue that there is still no perfect model for the detection of earnings management, i.e. measuring the size of discretionary accruals.

\subsection{The Practice of Earnings Management in the Industrial Sector of the Republic of Serbia and Other Countries}

According to the results of regression analysis conducted for each model (existing and modified model), we can conclude that our model has the greatest explanatory power for detecting manipulation of the financial results of the companies in the industrial sector of the Republic of Serbia. The model explained $63.7 \%$ of the total variance of the dependent variable. Therefore, our modified predictive model would be suitable for our future analysis, i.e. estimate the size of discretionary accruals in the Serbian business environment. The descriptive phase of the statistical data analysis is used for describing sample sizes, and all variables of the regression model. Table 9 presents the descriptive statistics for all variables of the modified model.

Since the nature of the changes of the observed characteristic is linearly dependent, we use the arithmetic mean as a measure of the average value. The mean value of discretionary accruals (DA) is 0.008 , or $0.8 \%$ of the average value of the total assets. This leads to the stated average size of earnings management of the company in relation to the average value of the assets. Since the discretionary accruals are positive, it means that in the industrial sector of the Republic of Serbia there is a practice of manipulating financial results to the higher value (financial result is increased). The 
Bešlić I. et al.: Testing the Models for Detection of Earnings Management

relationship between discretionary accruals (DA) and total accruals (TA) was investigated by using Pearson linear correlation coefficients. The results are presented in Table 10.

Table 9. Descriptive statistics for the variables of the modified model

\begin{tabular}{lcccccc}
\hline & $\mathrm{N}$ & Minimum & Maximum & Mean & Std. Deviation & Variance \\
\hline TA & 65 & -.3067223 & .3405067 & .007436917 & .1051646800 & .011 \\
\hline $\mathrm{NDA}$ & 65 & -.1572963 & .2023959 & -.000650195 & .0752101369 & .006 \\
\hline $\mathrm{DA}$ & 65 & -.1857824 & .2061241 & .008087111 & .0783083252 & .006 \\
\hline $\begin{array}{l}\text { Valid } \\
\text { (listwise) }\end{array}$ & $\mathrm{N}$ & 65 & & & & \\
\hline
\end{tabular}

Source: authors' research

Table 10. Correlation coefficients

\begin{tabular}{|c|c|c|c|c|}
\hline & & TA & NDA & DA \\
\hline \multirow{3}{*}{ TA } & Pearson Correlation & 1 & $.669^{* *}$ & $.700^{* *}$ \\
\hline & Sig. (2-tailed) & & .000 & .000 \\
\hline & $\mathrm{N}$ & 65 & 65 & 65 \\
\hline \multirow{3}{*}{ NDA } & Pearson Correlation & $.669^{* *}$ & 1 & -.062 \\
\hline & Sig. (2-tailed) & .000 & & .624 \\
\hline & $\mathrm{N}$ & 65 & 65 & 65 \\
\hline \multirow{3}{*}{ DA } & Pearson Correlation & $.700^{* *}$ & -.062 & 1 \\
\hline & Sig. (2-tailed) & .000 & .624 & \\
\hline & $\mathrm{N}$ & 65 & 65 & 65 \\
\hline
\end{tabular}

Note: ${ }^{*}$. Correlation is significant at the 0.01 level (2-tailed).

Source: authors' research

The Pearson correlation coefficient (0.700) is positive, which indicates a positive correlation between discretionary accruals (DA) and total accruals (TA). If the value of discretionary accruals is greater, then the value of total accruals is greater. The absolute value of the coefficient indicates the strength of the connection. Between these two variables there is a strong correlation 
Bešlić I. et al.: Testing the Models for Detection of Earnings Management

(correlation coefficient $(r)$ is above 0.5 ), which indicates the strong relationship between discretionary accruals (DA) and total accruals (TA) (Cohen, 1988). Pearson correlation $r=0.700$ when is squared gives $49 \%$ of the common variance. The level of statistical significance shows with how much confidence we can observe the results. The resulting amount of the correlation coefficient is statistically significant (Sig. (2-tailed) $=0.000, p<0.01$ ).

In the pre-Sarbanes-Oxley (SOX) period (before 2002), discretionary accruals were relatively higher - from $1 \%$ to $5 \%$ of the total assets of US corporations (Dechow et al., 1995). Nor Farhana, Nor Balkish and Zuraidah (2014) find significant different in mean for earnings management between listed companies in Malaysia and Thailand. Data is based on 335 public listed companies in Malaysia and 224 public listed companies in Thailand (20102012). The study shows that average absolute discretionary accruals estimated using Dechow model (1995) for public listed companies in Malaysia, is $5.9 \%$ of the total assets and average absolute discretionary accruals for public listed companies in Thailand is $7.2 \%$ of the total assets. Leuz, Nanda and Wysocki (2003) classify sample countries into three clusters. The first cluster includes outsider economies with large stock markets, dispersed ownership, strong investor rights, and strong legal enforcement (Singapore, Hong Kong, Malaysia, the UK, Norway, Canada, Australia, and the USA); the second includes insider economies with lessdeveloped stock markets, concentrated ownership, weak investor rights, and strong legal enforcement (Austria, Taiwan, Switzerland, Germany, Japan, Belgium, Netherlands, Denmark, France, Finland, Sweden, South Africa, and Ireland); the third includes insider economies with weak legal enforcement (Greece, Korea, Portugal, Italy, India, Spain, Indonesia, Thailand, Pakistan, and the Philippines). They find that earnings management scores among the three clusters are significant and that outsider economies with relatively dispersed ownership, strong investor protection, and large stock markets exhibit lower levels of earnings management than insider countries with relatively concentrated ownership, weak investor protection, and less developed stock markets. The previous analyses suggest that the pervasiveness of earnings management is systematically related to a country's institutional characteristics (law system, accounting practice and disclosure, investor protection, development of capital market etc.).

Business activities in the conditions of the global economic crisis (recession period) are characterized by the practice of manipulating the financial results of the management of the company. Chia, Lapslley and Lee (2007) concluded that during the Asian financial crisis (1997/1998) earnings management usually resulted in decrease of net income, because managers have motives for "big bath" significantly reducing the financial result by decrease in revenues or increase in expenses in the current period. That leads to the 
Bešlić I. et al.: Testing the Models for Detection of Earnings Management

better financial results in future operations. According to Wall and Wilk (2010) reduction of net income followed by "big bath" was insignificant during the crisis period.

\section{Conclusions}

The existing models of discretionary accruals, such as Jones model (1991), Dechow model (1995), Kasznik model (1999), etc., do not include independent variables in order to reveal the effects of the initial and subsequent measurement of inventories, property, plant and equipment on the financial statements. Accordingly, a modified predictive model has been developed and it includes the monitoring of these effects. The existing models of discretionary accruals have different explanatory power in the detection of earnings management of the companies in the industrial sector of the Republic of Serbia (Jones model 5.4\%; Dechow model 2.6\%; Kasznik model $37 \%$ ). Our modified model shows improved explanatory power of the dependent variable, which is $63.7 \%$.

The empirical results of the study confirm the hypothesis that the application of the model of discretionary accruals may detect earnings management in the industrial sector of the Republic of Serbia. In times of crisis companies in the industrial sector of the Republic of Serbia show better financial results than they actually made. The mean value of discretionary accruals (DA) for a sample of 65 companies in the industrial sector of the Republic of Serbia in the period between 2010 and 2011 totals about 0.008 , or $0.8 \%$ of the average value of total assets, which means that in the industrial sector of the Republic of Serbia there is a practice of manipulating financial results to the higher value (financial result is increased). There is a positive and statistically significant correlation between discretionary accruals and total accruals (Sig. (2-tailed) $=0.000, p<0.01)$. The empirical results of the research support previous research that business activities in the conditions of the global economic crisis (recession period) and post-IFRS period are characterized by the practice of manipulating the financial results of the management of the company. Empirical studies provide evidence that accruals estimation models vary in their predictive power when assessed in dissimilar environments, given the differences between countries regarding accounting systems, economic performance, institutional features and social, legal and political environment that affect financial data. Future research should be directed towards the further development of the model to detect manipulative financial reporting of various business entities and their adaptation in the application by their different users: auditors, investors, creditors, tax authorities, financial analysts and other interested parties. 
Bešlić I. et al.: Testing the Models for Detection of Earnings Management

\section{References}

Alareeni, B., \& Aljuaidi, O. (2014). The Modified Jones and Yoon Models in Detecting Earnings Management in Palestine Exchange (PEX). International Journal of Innovation and Applied Studies, 9(4), 1472-1484.

Algharaballi, E. (2012). Listing year Discretionary Accruals by Kuwaiti Shareholding Closed Companies (KSCCs). International Conference on Business, Economics, Management and Behavioral Sciences (ICBEMBS'2012), Dubai, 527-532. Retrieved from: http://psrcentre.org/images/extraimages/0112224.pdf [visited on 1 February 2014]

Ali, S. M., Salleh, N. M., \& Hassan, M. S. (2008). Ownership Structure and Earnings Management in Malaysian Listed Companies: The Size Effect. Asian Journal of Business and Accounting, 1(2), 89-116.

Andrić, M., \& Vuković, B. (2012). Reflections of the Crisis on the Corporate Operational Performance of Serbian Industrial Companies. Strategic Management, 17(3), 21-28.

Arsić, M. (2011). Fiskalna politika u Srbiji u uslovima novog talasa krize i produžene recesije [Fiscal Policy in Serbia in Terms of the New Wave of the Crisis and Prolonged Recession]. Quarterly Monitor of Economic Trends and Policies in Serbia, No. 25 and 26, Belgrade: Fondacion for the Advancement of Economic Science (FREN). Retrieved from: http://www.fren.org.rs/sites/default/files/qm/QM25-26.pdf [visited on 20 July 2015]

Asif, M.K., Rehana, F., \& Md. Mamunur, R. (2011). Cosmetic Accounting Practices in Developing Countries: Bangladesh Perspectives. World Journal of Social Sciences, $1(3), \quad 1-15 . \quad$ Retrieved from: http://www.wjsspapers.com/static/documents/July/2011/1-\%20Asif.pdf [visited on 1 February 2014]

Beaver, W.H. (2002). What Have We Learned from the Recent Corporate Scandals that We Did Not Already Know?, Stanford Journal of Low Business \& Finance, 8(1), 155-156.

Bešlić, I., \& Bešlić, D. (2009). Uticaj svetske ekonomske krize na poslovanje preduzeća u Srbiji [The Influence of the Global Financial Crisis on the Performance of Companies in Serbia]. Scientific Meeting - Business Environment in Serbia and Global Financial Crisis, Novi Sad: Business School.

Business Registers Agency of the Republic of Serbia. (2014). Retrieved from: http://pretraga2.apr.gov.rs/ObjedinjenePretrage/Search/Search

Chen, K.Y., Lin, K.L., \& Zhou, J. (2005). Audit Quality and Earnings Management for Taiwan IPO firms. Managerial Auditing Journal, 20(1), 86-104.

Chia, Y. M., Lapslley, I., \& Lee, H.W. (2007). Choice of Auditors and Earnings Management During the Asian Financial Crisis. Managerial Auditing Journal, 22(2), 177-196.

Cohen, J.W. (1988). Statistical Power Analysis for the Behavioral Sciences (2nd ed.). Hillsdale, NJ: Lawrence Erlbaum Associates.

Collingwood, H. (2001). The Earnings Game: Everyone Plays, Nobody Wins. Harvard Business Review, 79(6), 65-74.

De las Heras, E., Canibano, L., \& Moreira, J.A. (2012). The Impact of the Spanish Financial Act (44|2002) on Audit Quality, Revistaespañola de financiación y 
Bešlić I. et al.: Testing the Models for Detection of Earnings Management

Contabilidad - Spanish Journal of Finance and Accounting (REFC), 41(156), 521-546.

Dechow, P.M., Sloan, R.G., \& Sweeney, A.P. (1995). Detecting Earnings Management. The Accounting Review, 70(2), 193-225.

Fawzi, S.M. (2014). Naive Investor Hypothesis Application in Jordan. Interdisciplinary Journal of Contemporary Research in Business, 5(11), 232-253.

Financial Accounting Standards Board. (1987). Statement No. 95, Statement of Cash Flows. Stamford, Conn.: FASB.

Healy, P.M. (1985). The Effect of Bonus Schemes on Accounting Decisions. Journal of Accounting and Economics, 7(1-3), 85-107.

Hribar, P., \& Collins, D.W. (2002). Errors in Estimating Accruals: Implications for Empirical Research. Journal of Accounting Research, 40, 105-134.

Jakšić, D., \& Vuković, B. (2012). Uticaj krize na manipulisanje finansijskim izveštajima [The Influence of Crisis on the Manipulation of Financial Reports]. Proceedings of the 16th Congress of Accountants and Auditors of the Republic of Srpska: BanjaVrućica.

Jeanjean, T., Stolowy, H. (2008). Do Accounting Standards Matter? An Exploratory Analysis of Earnings Management Before and After IFRS Adoption. Journal of Accounting and Public Policy, 27, 480-494.

Joksimović, D. (2006). Poslovna statistika [Business Statistics]. Belgrade: Megatrend University of Applied Sciences.

Jones, J.J. (1991). Earnings Management During Import Relief Investigations. Journal of Accounting Research, 29(2), 193-228.

Kasznik, R. (1999). On the Association Between Voluntary Disclosure and Earnings Management. Journal of Accounting Research, 37(1), 57-81.

Kirschenheiter, M., \& Melumad, N.D. (2002). Can "Big Bath" and Earnings Smoothing Coexist as Equilibrium Financial Reporting Strategies?, Journal of Accounting Research, 40(3), 761-796.

Kothari, S.P., Leone, A.J., \& Wasley, C.E. (2005). Performance Matched Discretionary Accrual Measures. Journal of Accounting Economics, 39(1),163-197.

Larcker, D.F., \& Richardson, S. A. (2004). Fees Paid to Audit Firms, Accrual Choices and Corporate Governance. Journal of Accounting Research, 42(3), 625-658.

Leuz, C., Nanda, D., \& Wysocki, P.D. (2003). Earnings Management and Investor Protection: an International Comparison. Journal of Financial Economics, 69, 505-527.

Matis, D., Beattrice, V.A., \& Negrea, L. (2009). Cash-flow Reporting between Potential Creative Accounting Techniques and Hedging Opportunities Case Study Romania. Annales Universitatis Apulensis Series Oeconomica, 11(1), 140-153.

Matis, D., Beattrice, V.A., Negrea, L., \& Sucala, L. (2010). Jones, Dechow and Kasznik Models Significance in the Romanian Economic Environment. Annales Universitatis Apulensis Series Oeconomica, 12(1), 253-266.

McNichols, M. (2000). Research Design Issues in Earnings Management Studies. Journal of Accounting and Public Policy, 19, 313-345.

Md. Aminul, I., Ruhani, A., \& Zamri, A. (2011). Is Modified Jones Model Effective in Detecting Earnings Management? Evidence from a Developing Economy. International Journal of Economics and Finance, 3(2), 116-125.

Md. Borhan, U.B., Jamal, R., \& Murray, C. (2013). Corporate Governance Compliance and Discretionary Accruals: New Zealand Evidence. Australasian Accounting. Business and Finance Journal, 7(2), 101-124. 
Bešlić I. et al.: Testing the Models for Detection of Earnings Management

Nor Farhana, S., Nor Balkish, Z., \& Zuraidah Mohd., S., (2014). Remodelling the Earnings Management with the Appearance of Leverage, Financial Distress and Free Cash Flow: Malaysia and Thailand Evidences. Journal of Applied Sciences, 14, 2644-2661.

The Ministry of Finance of the Republic of Serbia. (2013). International Accounting Standards (IAS)/International Financial Reporting Standards (IFRS) translation, Serbia: Belgrade.

Mulford, C.W., \& Comiskey, E.E. (2002). The Financial Numbers Game: Detecting Creative Accounting Practices. New York: John Wiley \& Sons.

Naveed, A., Saif, M.I., Qaisar, A.M., \& Shoaib, H. (2012). Earnings Management and Firms' Profitability Evidence from Pakistan. European Journal of Economics, Finance and Administrative Sciences, 47, 13-18.

Pallant, J. (2009). SPSS: priručnik za preživljavanje [SPSS: Guide for Survival]. Belgrade: Mikroknjiga.

Peasnell, K., Pope, P., \& Young, S. (2000). Detecting Earnings Management using Cross Sectional Abnormal Accruals Models. Accounting and Business Research, 30(4), 313-326.

Rahman, A. R., \& Ali, F. (2006). Board, Audit Committee, Culture and Earnings Management: Malaysian Evidence. Managerial Auditing Journal, 21(7), 783-804.

Roodposhti, F.R, Banimahd, B., Rezaei, S., \& Salehi, A. (2012). Analysis of Power and Specification of Accruals-Based models to Detect Earnings Management. Journal of Basic and Applied Scientific Research, 2(10), 9961-9969.

Sandeep, G. (2012). Demystifying Earnings Management Through Accruals Management: an Indian Corporate Study. VIKALPA, 37(1), 49-56.

Soldić-Aleksić, J. (2011). Primenjena analiza podataka [Applied Data Analysis], Belgrade: Faculty of Economics in Belgrade, Čugura print-Belgrade.

Stubben, S.R. (2010). Discretionary Revenues as a Measure of Earnings Management. The Accounting Review, 85(2), 695-717.

Tilden, C., \& Janes T. (2012). Empirical Evidence of Financial Statement Manipulation During Economic Recessions. Journal of Finance and Accountancy, 10, 1-15. Retrieved from: http://www.aabri.com/manuscripts/121125.pdf [visited on 1 February 2014]

Wang, B., \& Xin, Q. (2011). Auditor Choice and Accruals Patterns of Cross-Listed Firms. China Journal of Accounting Research, 4(4), 233-251. Retrieved from: http://www.sciencedirect.com/science/article/pii/S1755309111000281 [visited on 31 August 2015]

Wall, J., \& Wilk, M. (2010). Earnings Management och Finanskrisen. Sweden: Uppsala Universitet.

Yoon, S., Miller, G., \& Jiraporn, P. (2006). Cash from Operations and Earnings Management in Korea. Journal of International Financial Management and Accounting, 17(2), 85-109. 